\title{
Antibacterials Drugs: Prescriptive Appropriety in the Covid-19 Emergency
}

\author{
Domenica Ancona ${ }^{1}$, Cataldo Procacci ${ }^{1 *}$, Romina Giannini ${ }^{1}$, Francesco Barbara ${ }^{2}$, Antonio Germinario ${ }^{3}$ and $^{-}$ \\ Alessandro Delle Donne ${ }^{3}$ \\ ${ }^{1}$ Pharmaceutical Department, Local Health Authority of Barletta, Italy
}

${ }^{2}$ Department of Otolaryngology, Local Health Authority of Barletta, Italy

${ }^{3}$ General Direction, Local Health Authority of Barletta, Italy

Submission: February 21, 2021; Published: March 03, 2021

*Corresponding author: Cataldo Procacci, Pharmaceutical Department, Local Health Authority of Barletta-Andria-Trani, Italy

\section{Letter to Editor}

The new coronavirus disease 2019 (COVID-19) is a highly contagious zoonosis produced by SARS-CoV-2, it is spread from human to human via respiratory secretions. It is a public health emergency that has strained health systems around the world and could also have negative implications for the fight against antimicrobial resistance. As we well know, during the first months of the pandemic, empirical therapies with antibiotics were conducted, especially in hospitals, for patients suffering from coronavirus infection, this is a fact that has opened a great debate, especially for the risks of antibiotics resistance. From the medical records analyzed, today it appears that over $90 \%$ of patients with Covid-19 receive empiric antibiotic therapy, this because, in these months of emergency, attention to this phenomenon was not a priority. Among the negative effects of the pandemic on the fight against hospital infections we must also consider the overload of the diagnostic laboratories, which has made the work on the surveillance of pathogens harder.

In addition, in the first months of the pandemic there was a significant increase in the consumption of non-therapeutic medicines: in particular, hydroxychloroquine and azithromycin, some antivirals and interleukin inhibitors. Azithromycin has been used in various protocols in association with hydroxychloroquine (a drug already authorized for the treatment of malaria and some autoimmune diseases) to treat patients with COVID-19 [1,2]. Clinical improvement has been documented in most of the treated patients, but the number of treated subjects is still small to be able to draw clear and definitive conclusions.

In hospitalized patients, in Italy as in the rest of the world, there was a sharp increase in the consumption of antibiotics. During the first months of the outbreak COVID-19, an Italian study conducted in Milan, Italy, found that two out of three COVID-19 patients received at least one course of antibiotics during their hospital stay [3], and the proportion was even higher $(80 \%)$ in a hospital in Barcelona, Spain [4]. In the first half of 2020 the consumption of drugs, through the affiliated pharmacies, is 13,2 per 1000 inhabitants per day, down by $-26.3 \%$ compared to the same period of the previous year.

This trend is partly due to the national lockdown between March and May 2020, which minimized the movement of the population, to the modification of organizational models (access to the clinics of General Practitioners and Pediatricians, use of the electronic prescription) and to the use of personal protective equipment, which may have reduced the transmission of bacterial infections [5]. The local health authority of Barletta-Andria-Trani (LHA BT) operates in the territory coinciding with the province of BT (Barletta-Andria-Trani) with a population of 391,224 inhabitants. This was one of the areas with the highest infection rates in the Puglia Region during the first pandemic phase.

In the LHA BT hospitals, in the first half of 2020, there was a $+16.9 \%$ increase in the consumption of antibiotics (ATC J01) compared to the same period of 2019. The largest increases were recorded in the therapeutic class of combination penicillin's $(\mathrm{J} 01 \mathrm{CR}+15 \%)$, in the therapeutic class of carbapenems $(\mathrm{J} 01 \mathrm{DH}+12,6 \%)$, in the therapeutic class of 1 st generation cephalosporins (J01DB+12,7\%), 3rd generation cephalosporins (J01DD+10,1\%), broad spectrum penicillin's (J01CA+6,65\%) and of the therapeutic class of macrolides (J01FA+6,36\%).

The trend in antibiotic consumption showed a peak in March 2020, when the first cases of Covid-19 were isolated in LHA $\mathrm{BT}$, and then decreased in the last two months of the semester. Considering the cancellation of the planned surgical and medical activity, a reduction in the consumption of antibiotics would have 


\section{Global Journal of Otolaryngology}

been expected, also considering the lower risk of contracting infections associated with health care, but this did not happen because in the very early stages of the pandemic patients entered the hospital with symptoms like community pneumonia and the times with which the molecular tests were processed were less rapid than the current ones. In this situation, considering that there was also a lack of clear indications on the therapeutic treatments to be used in cases or suspected Covid-19 cases and there were fears of bacterial infections concomitant with the viral one, the use of antibiotics was an empirical choice, as referred by Lai et al. [6] who have shown empirical antibiotic use in $90 \%$ of patients, despite poor confirmation of secondary bacterial infections (10\%). The use of antibiotics has declined as knowledge about SARS-CoV-2 has increased (Figures $1 \& 2$ ).

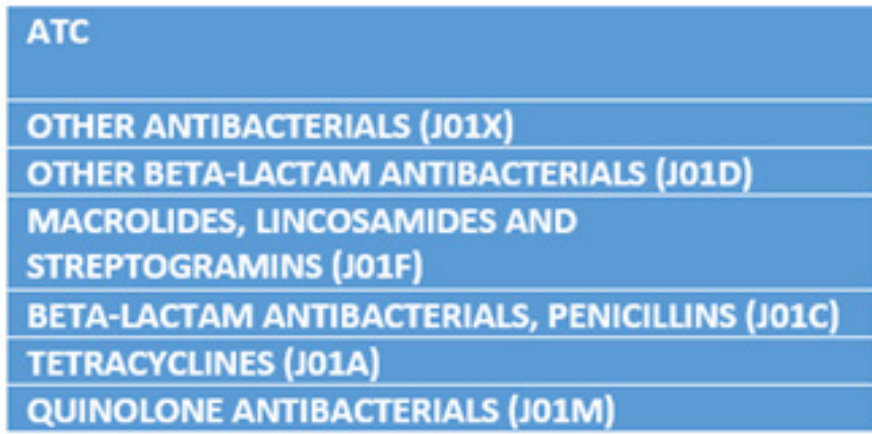

\begin{tabular}{|r|}
\hline DDD 1H \\
\hline 2019 \\
\hline 12.998 \\
\hline 246.92 \\
\hline 205.484 \\
\hline 219 \\
14 \\
277 \\
\hline
\end{tabular}

DDD $1 \mathrm{H}$

Difference

Diff \% 2020

150.801

137.803

$1060 \%$

246.92

86.5

$-160.42$

$-65 \%$

69.71

$-135.774$

$-66 \%$

\begin{tabular}{|r|r|r|r|}
\hline 219 & 49.2 & -169.8 & $-78 \%$ \\
\hline 14 & & -14 & $-100 \%$ \\
\hline 277 & & -277 & $-100 \%$ \\
\hline
\end{tabular}

Figure 1: Consumption of antibiotics (ATC J01) in the Department of Otolaryngology.

\begin{tabular}{|c|c|c|c|c|c|}
\hline $\begin{array}{l}\text { Hospitalization } \\
\text { regime }\end{array}$ & Diagnosis Related Group & $\begin{array}{l}\text { Total number of } \\
\text { hospitalizations }\end{array}$ & $\begin{array}{c}\text { Days of } \\
\text { hospitalization } \\
\text { in ordinary } \\
\text { hospitalization }\end{array}$ & $\begin{array}{c}\text { Total } \\
\text { admissions in } \\
\text { day hospital }\end{array}$ & $\begin{array}{c}\text { DRG } \\
\text { average } \\
\text { weight }\end{array}$ \\
\hline \multirow[t]{2}{*}{ day-hospital } & surgical & 20 & & 45 & 0.9445 \\
\hline & medical & 7 & & 10 & 0.5262 \\
\hline \multirow[t]{2}{*}{$\begin{array}{l}\text { ordinay } \\
\text { hospitalization }\end{array}$} & surgical & 319 & 1,614 & & 1.3138 \\
\hline & medical & 109 & 564 & & 0.6534 \\
\hline \multicolumn{2}{|c|}{ First half of 2019 (no-Covid) } & 455 & 2,178 & 55 & 1.1273 \\
\hline day-hospital & surgical & 14 & & 36 & 0.8607 \\
\hline \multirow{2}{*}{$\begin{array}{l}\text { ordinay } \\
\text { hospitalization }\end{array}$} & surgical & 245 & 1,678 & & 1.6645 \\
\hline & medical & 56 & 343 & & 0.7044 \\
\hline \multicolumn{2}{|c|}{ First half of 2020 (Covid) } & 315 & 2,021 & 36 & 1.4581 \\
\hline
\end{tabular}

Figure 2: Hospitalization activities of the Department of Otolaryngology.

For the Otolaryngology department, with an endowment of $n .16$ beds for oncological surgery, in contrast to the general data, there was a total decrease in the consumption of antibiotic specialties, compared to the first half of the previous year, as more effective management policies for antibiotic drugs were implemented and visitors' entry into the ward was carefully managed. In the context of affiliated pharmacies, in the first half of 2020 there was a decrease in DDD consumption (Defined Daily Dose) of $-27.9 \%$ compared to the first half of 2019. A more significant decrease was measured for 3rd generation cephalosporins, where there was a reduction in consumption of $-32.5 \% \mathrm{y} / \mathrm{y}$ (Italy-30.71\% y/y). A minor reduction occurred for macrolide antibiotics for the above reasons (LHA BT $-24.53 \% \mathrm{y} / \mathrm{y}$,
Italy $-18.92 \% \mathrm{y} / \mathrm{y}$ ] [7]. All rates of inappropriate use of antibiotics are still decreasing, but the use of:

a. amoxicillin and clavulanic acid in children (instead of amoxicillin alone)

b. any antibiotic following a diagnosis of flu, common cold or acute laryngotracheitis.

c. the use of fluoroquinolones and cephalosporins with a diagnosis of pharyngitis and acute tonsillitis

d. the use of macrolides as the first line of treatment for pharyngitis and acute tonsillitis (due to the high risk of developing resistance), 
e. in uncomplicated cystitis, the first line use of any antibiotic belonging to the class of fluoroquinolones.

In the scenario in which the pressure on the health system and on operators is high, and the attention of the scientific community is focused on combating the advance of the virus, the ability to develop strategies to control the phenomenon of antibiotic resistance has been significantly reduced. In the hospital setting, specific recommendations on the use of antibiotics in Covid-19 patients should be developed and in-hospital programs for controlling antibiotic resistance should be strengthened. On the other hand, in the context of General Practitioners and affiliated pharmacies, improving prescribing appropriateness, especially when it comes to antibiotics and their frequent abuse, can also mean leveraging behavioral aspects that can influence the therapeutic choices of physicians.

On 18 February, the G7 meeting of the Ministers of Health reaffirmed the priority commitment to the fight against antibiotic resistance. In the contributions of the ministers, the European Commissioner and all the other speakers, the situation on the initiatives against antibiotic resistance was discussed as one of the main global challenges for the protection of health. Among the topics covered in his speech, the Italian Minister Speranza stressed the need to "aim for public and private investments, even at an international level, to 'disconnect' research on antibiotic resistance from commercial dynamics alone” [8]. These drugs, over time, from being a health tool, have become a consumer good, triggering a dangerous circle that could bring the world back to the pre-antibiotic era.

\section{References}

1. Gautret P, Jean Christophe Lagier, Philippe Parola, Van Thuan Hoang, Line Meddeb, et al. (2020) Hydroxychloroquine and azithromycin as a treatment of COVID-19: results of an open-label non-randomized clinical trial. Int J Antimicrob Agents 20:105949.

2. Gautret P, Jean Christophe Lagier, Philippe Parola, Van Thuan Hoang, Line Meddeb et al. (2020) Clinical and microbiological effect of a combination of hydroxychloroquine and azithromycin in 80 COVID-19 patients with at least a six-day follow up: A pilot observational study. Travel Med Infect Dis 11:101663.

3. Giacomelli A, Ridolfo A L, Milazzo L (2020) 30-day mortality in patients hospitalized with COVID-19 during the first wave of the Italian epidemic: a prospective cohort study. Pharmacol Res 158:104931.

4. Garcia Vidal C, Sanjuan G, Moreno García E (2021) Incidence of coinfections and superinfections in hospitalized patients with COVID-19: a retrospective cohort study. Clin Microbiol Infect 27(1): 83-88.

5. L'uso degli antibiotici in Italia - Rapporto Nazionale 2019. 20 Dicembre 2020

6. Lai C C, Shih T P, Ko W C, Tang H J, Hsueh P R (2020) Severe acute respiratory syndrome coronavirus 2 (SARS-CoV-2) and coronavirus disease-2019 (COVID-19): The epidemic and the challenges. Int Antimicrob. Agents 55: 105924.

7. C Procacci, G Grimaldi, R Giannini, A Cirillo, D Ancona, et al. (2020) Donne - Use of antibiotic specialties during the covid-19 epidemic. Analysis of territorial consumption in an LHA in southern Italy. Abstract presented at the $7^{\text {th }}$ Edition 2020 of the FarmacistaPiù Congress.

8. Fight against antibiotic resistance and discussion on Covid-19 variants at the G7 center of health ministers.

\section{Your next submission with Juniper Publishers will reach you the below assets}

- Quality Editorial service

- Swift Peer Review

- Reprints availability

- E-prints Service

- Manuscript Podcast for convenient understanding

- Global attainment for your research

- Manuscript accessibility in different formats

( Pdf, E-pub, Full Text, Audio)

- Unceasing customer service

Track the below URL for one-step submission https://juniperpublishers.com/online-submission.php 